\title{
Biotic dispersal in eelgrass Zostera marina
}

\author{
Sarah E. Sumoski*, Robert J. Orth \\ Virginia Institute of Marine Science, College of William and Mary, P. O. Box 1346, Gloucester Point, Virginia 23062, USA
}

\begin{abstract}
Dispersal is a critical process in the life history of nearly all plant species and can be facilitated by both abiotic and biotic mechanisms. Despite an abundance of vertebrate fauna utilizing seagrass meadows as a feeding area and thus capable of consuming and excreting seeds, little work has been conducted on biotic seed dispersal mechanisms. The objectives of this study were to (1) determine whether seeds of the seagrass Zostera marina could pass through the digestive systems of resident and transient vertebrates of a seagrass bed and remain viable and (2) determine seed retention times in the guts of each species to estimate dispersal distances of $Z$. marina seeds by vertebrate dispersers. Excretion and germination rates of consumed seeds for 3 fish species (Fundulus heteroclitus, Sphoeroides maculatus, Lagodon rhomboides), 1 turtle species (Malaclemys terrapin) and 1 waterfowl species (Aythya affinis) showed $Z$. marina seeds could survive passage through species' digestive systems and successfully germinate. Excretion rates were generally highest for $F$. heteroclitus, S. maculatus, and M. terrapin, lowest for A. affinis, and moderate for L. rhomboides. Analyses suggest seeds were significantly affected by species' digestive tracts. Maximum dispersal distances are estimated to be 200,60,1500, and $19500 \mathrm{~m}$ for F. heteroclitus, L. rhomboides, M. terrapin, and A. affinis, respectively. Data here provide strong evidence that biotic dispersal can occur in Z. marina, and biotically transported seeds can be dispersed to isolated areas unlikely to receive seeds via abiotic mechanisms. Biotic dispersal may rival or exceed abiotic mechanisms. Future seagrass dispersal models should incorporate biotic dispersal as a seed transport mechanism.
\end{abstract}

KEY WORDS: Seeds · Dispersal · Vertebrates · Zostera marina

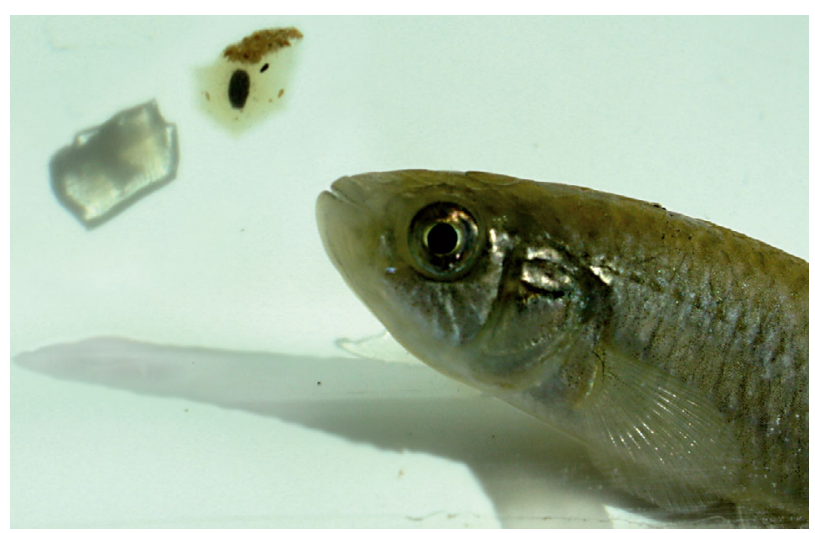

Fundulus heteroclitus were fed Zostera marina seeds in a squid gelatin matrix.

Image: Scott Marion

\section{INTRODUCTION}

Dispersal is widely recognized as a critical process in the life history of nearly all plant species (Levin et al. 2003, Nathan et al. 2008). Its benefits have profound impacts on plant populations by establishing new populations away from the parent plant, thereby increasing chances of survival for the dispersing propagule (Howe \& Smallwood 1982). Dispersal mechanisms can be abiotic or biotic. Each plant species may rely on one specific dispersal mechanism based on life-history characteristics (e.g. wind- or current-dispersed seeds), although, it is more likely that seeds of many species are dispersed by multiple mechanisms, both abiotic and biotic (e.g. wind and animal dispersers; Howe \& Smallwood 1982, Herrera 2002), prior to entering the seed bank (Chambers \& MacMahon 1994, Wilkinson 1997, 1999, Higgins et al. 2003). Recent evidence suggests long-distance 
dispersal events may be more common than previously considered, regardless of the life-history traits of plants (Clark et al. 1998, Nathan et al. 2008).

In terrestrial systems, biotic dispersal of propagules occurs through ingestion and excretion of viable seeds or via seeds externally attached to the body of the dispersing agent (Chambers \& MacMahon 1994, Debussche \& Isenmann 1994, Figuerola et al. 2002, Figuerola \& Green 2004). Biotic dispersal distances can range from meters to kilometers, depending on the dispersal agent (e.g. ants and deer, respectively; Myers et al. 2004). Despite knowledge of terrestrial biotic dispersal processes, little is known about them in marine angiosperms, the seagrasses, and whether seeds can actually survive passage through the gut of different species.

Seagrasses are found in most shallow coastal waters around the world (Green \& Short 2003) and can reproduce both asexually (rhizome elongation) and sexually (seeds). Currently, mechanisms of dispersal in seagrasses have been described as primarily abiotic, via winds and currents acting on floating propagules (Churchill et al. 1985, Orth et al. 2006, Kendrick et al. 2012). Few studies have highlighted biotic dispersal mechanisms, e.g. waterfowl (Agami \& Waisel 1986, 1988, Charalambidou et al. 2003). A number of vertebrate species, including sireniens, turtles, waterfowl, and fishes (Cottam et al. 1944, Adams 1976, Kendrick et al. 2012), are known to consume seagrass through either direct feeding on shoots which may contain seeds or indirect feeding on the associated epiphytes and epifauna (Thayer et al. 1984). Several feeding studies of fauna that inhabit seagrass beds have found either seed fragments or entire seeds in their guts (Adams 1976, Figuerola et al. 2003, Sumoski \& Tulipani pers. obs.), providing evidence that seeds are ingested in the foraging process. Observations indicate that much of the ingested material, including seeds if present, may be excreted with minimal damage (Thayer et al. 1984).

This study investigates biotic dispersal mechanisms in the seagrass Zostera marina (eelgrass). $Z$. marina is widely distributed in the North Atlantic and Pacific Oceans and in the Mediterranean Sea (Green \& Short 2003). It is abundant in the Chesapeake Bay region, USA, where it produces seeds in flowering shoots from late May to early June. Currently, reported dispersal mechanisms for Z. marina are abiotic and include floating seeds, floating reproductive shoots with mature seeds, and seeds moving across the sediment from currents (Churchill et al. 1985, Orth et al. 1994, Harwell \& Orth 2002). However, Z. marina supports dense populations of animals, including fishes and waterfowl, acting as both habitat and a food source for these occupants (Adams 1976, Thayer et al. 1984, Moore \& Short 2006, authors' pers. obs.).

While some studies have examined the consumption of seeds of several different seagrass species by fauna (Agami \& Waisel 1986, 1988, Charalambidou et al. 2003), none have examined biotic dispersal of Zostera marina nor estimated the dispersal distances of resident and non-resident species that may consume seeds. Our objectives in this study were to (1) determine whether $Z$. marina seeds can pass through the guts of different resident and transient vertebrates and remain viable and (2) determine seed retention times in the guts of each species to estimate dispersal distances of $Z$. marina seeds by vertebrate dispersers.

\section{MATERIALS AND METHODS}

Zostera marina seeds for the feeding experiments were obtained from mature flowering shoots present in Z. marina meadows in late May to early June, 2009 to 2011, in South Bay on the seaside of the Delmarva Peninsula, Virginia, USA ( $\left.37^{\circ} 16^{\prime} 20^{\prime \prime} \mathrm{N}, 75^{\circ} 48^{\prime} 51^{\prime \prime} \mathrm{W}\right)$. Seeds were separated from reproductive shoots and stored using methods described by Marion \& Orth (2010). Prior to feeding trials, seeds were assessed for viability by gently squeezing them and checking individual fall velocities (Marion \& Orth 2010).

\section{Feeding trials}

Five possible biotic dispersal species representing a range of vertebrate types found in Zostera marina beds within Chesapeake Bay were chosen for feeding trials based on literature reports of the presence of $Z$. marina seeds in guts, abundance in seagrass beds, foraging strategy that would allow for the ingestion of seeds, or personal observations (Table 1). Three species were assumed to have a short dispersal potential of $<1 \mathrm{~km}$ : Fundulus heteroclitus (mummichog), Sphoeroides maculatus (northern puffer), and Lagodon rhomboides (pinfish); and 2 species showed the potential to disperse seeds at distances $>1 \mathrm{~km}$ : Malaclemys terrapin (diamondback terrapin) and Aythya affinis (lesser scaup) (Adams 1976, Orth $\&$ Heck 1980, D. Tulipani unpubl. data). These species can ingest seeds either by feeding directly on $Z$. marina (L. rhomboides TL: $>80 \mathrm{~mm}, A$. affinis), or by 
Table 1. Number of individuals for each species used in the feeding trials and total number of seeds consumed for each trial year

\begin{tabular}{|lccc|}
\hline Taxon & $\begin{array}{c}\text { Trial } \\
\text { year }\end{array}$ & $\begin{array}{c}\text { No. of } \\
\text { individuals }\end{array}$ & $\begin{array}{c}\text { No. of seeds } \\
\text { consumed }\end{array}$ \\
\hline Fundulus heteroclitus & 2009 & 14 & 207 \\
& 2010 & 17 & 176 \\
Malaclemys terrapin & 2009 & 12 & 32 \\
& 2010 & 5 & 36 \\
Sphoeroides maculatus & 2009 & 1 & 3 \\
& 2010 & 2 & 28 \\
Lagodon rhomboides & 2011 & 9 & 84 \\
Aythya affinis & 2010 & 14 & 66 \\
& 2011 & 10 & 106 \\
& 2011 & 4 & 969 \\
\hline
\end{tabular}

indirectly consuming seeds by feeding on epiphytes and epifauna (L. rhomboides $<80 \mathrm{~mm}, F$. heteroclitus, $S$. maculatus, $M$. terrapin). Feeding trials were conducted from July to November in 2009, 2010, and 2011, based on the availability of species each year (Table 1).

Fishes and terrapins were collected from nearby Zostera marina meadows by trawling, seining, or using a minnow trap. Fishes were selected for length to ensure seed consumption, particularly Lagodon rhomboides which had been found to have $Z$. marina seeds present in their guts (Table 2 in Adams 1976). L. rhomboides undergoes an ontogenetic shift in feeding strategy from omnivory to herbivory between 80 and $120 \mathrm{~mm}$ (Stoner \& Livingston 1984). We used specimens that would be considered herbivorous (Table 2). Specimens were transported to the laboratory in aerated holding tanks. Individuals were kept in separate aerated aquaria. Test specimens were offered seeds placed in a feeding matrix (Fundulus heteroclitus: squid gelatin; L. rhomboides, Sphoeroides maculatus: shrimp; Malacemys terrapin:

Table 2. Number of specimens, mean fork length (mm), and mean weight $(\mathrm{g})$ of specimens used in the experiments for each species during the experimental period. nd $=$ no data

\begin{tabular}{|lcccc|}
\hline Taxon & Years & $\begin{array}{c}\text { No. of } \\
\text { specimens }\end{array}$ & $\begin{array}{c}\text { Mean fork } \\
\text { length } \pm \text { SD } \\
(\mathrm{mm})\end{array}$ & $\begin{array}{c}\text { Mean } \\
\text { weight } \pm \text { SD } \\
(\mathrm{g})\end{array}$ \\
\hline Fundulus heteroclitus & $2009-2010$ & 31 & $84.23 \pm 8.66$ & nd \\
Sphoeroides maculatus & $2010-2011$ & 4 & $143.75 \pm 26.57$ & nd \\
Lagodon rhomboides & $2010-2011$ & 14 & $123.36 \pm 13.57$ & nd \\
Malaclemys terrapin & $2009-2010$ & 14 & nd & $263.78 \pm 75.30$ \\
Aythya affinis & 2011 & 4 & nd & $681.25 \pm 15.48$ \\
\hline
\end{tabular}

blue crab claw). Prior to each experiment, test specimens were placed in individual aquaria and starved for 12 to $48 \mathrm{~h}$. At the initiation of each feeding trial, viable $Z$. marina seeds were placed in feeding matrices and subsequently fed to the test specimens. $M$. terrapin, S. maculatus, and L. rhomboides were fed 3 to 5 seeds for each feeding trial, while $F$. heteroclitus were fed seeds until satiated. Total number of seeds used for each species each year is given in Table 1. Non-consumed seeds were enumerated by either counting and removing fallen seeds at the bottom of the tank or by siphoning the bottom of the tank for seeds. In the 2010 and 2011 feeding trials, a mesh screen separated fish specimens from the bottom of each tank to prevent re-consumption of seeds. This behavior was noted during the $2009 \mathrm{~F}$. heteroclitus feeding trials. Fishes were left undisturbed for 24 to $48 \mathrm{~h}$ after feeding, at which time all excreted seeds, including damaged seeds or seed coats, were removed from tank bottoms, in order to determine excretion rates. Terrapin cages were cleaned daily, and water was sieved to extract excreted seeds, both whole, as well as damaged. Intact seeds were stored in $25 \mathrm{ml}$ vials containing each specimen's appropriate aquarium water. Lengths of feeding trials varied for all species, but generally were conducted until all seeds were excreted, or in a few individual cases, an additional $24 \mathrm{~h}$ beyond the species observed seed retention time (S. Sumoski pers. obs.).

Specific retention time of seeds in the guts of fishes was estimated by feeding either a single seed or glass bead mimic $\left(\sim 1 \mathrm{~mm}^{2}\right)$ to ensure no digestion occurred. We noted no difference in excretion times between seeds and beads when incorporated into the test. Fishes were then monitored hourly for seed or bead excretion. Retention time of seeds in the guts of Malacemys terrapin was estimated by monitoring excretion of seeds at frequent intervals during feeding trials.

Aythya affinis were held at the United States Geological SurveyPatuxent Wildlife Research Center, Maryland, USA. Individuals were fed seeds in a food slurry using Lafeber's Emeraid Exotic Carnivore Diet (Lafeber Company) to ensure their stomachs were full during the feeding trial ( $R$. Therrien pers. comm.). Specimens were then placed in individual 50 gallon (ca. 190 l) tubs with ambient seawater filled halfway, a mesh screen separating them from the bottom, and an 
opaque cover to minimize stress to the animal. Individuals were allowed to swim undisturbed for 6 to $7 \mathrm{~h}$ (observed seed retention time: 2 to $5 \mathrm{~h}$ ) after which the individuals were removed and the tubs were drained, with all water siphoned into a $1.0 \mathrm{~mm}$ sieve to retain excreted seeds - both damaged and intact. Retention time of seeds in the guts of $A$. affinis was determined by mixing a dye marker in the carnivore diet and monitoring for excretion of the marker.

Control experiments included 3 to 5 seeds being placed in each feeding matrix and salt water during each feeding trial for at least $2 \mathrm{~h}$ before being removed and placed in a vial for storage. A second control ('seawater control') consisted of seeds held in plain seawater. Controls for Aythya affinis consisted of seeds placed in the food slurry and seeds placed in the food slurry and dye combination.

\section{Germination tests}

Excreted seeds were stored in $25 \mathrm{ml}$ vials with seawater until November of each trial year, which immediately preceded the natural germination time of Zostera marina in Virginia (Moore et al. 1993). Seeds were planted in $1.0 \mathrm{~mm}$ sieved sediment collected from the York River, Virginia, USA. Seed planting depth was approximately 5 to $10 \mathrm{~mm}$. The location of each seed was recorded by specimen to ensure proper identification of each emergent seedling. Sediment containers with seeds were placed in an outdoor tank with standing water and covered with a shade cloth. Temperature and salinity were monitored and kept at ambient conditions matching those of the neighboring York River. Ice was removed as necessary. Seedling emergence was monitored weekly until March, at which time the sediment was sieved through a $1.0 \mathrm{~mm}$ sieve and all seedlings and ungerminated seeds were removed and counted. Seedlings were identified based on the presence of a cotyledon or green shoot. Seeds which had not germinated were stripped of their seed coat and soaked in a $1.0 \%$ Tetrazolium staining solution for $24 \mathrm{~h}$ to determine the presence of living tissue, an indication of seed viability (Conacher et al. 1994).

Dispersal distances of each species were estimated using reported movement rates based on literature values and observed seed retention times in the guts of individual species. These estimates were then compared to distances reported for abiotic dispersers.

\section{Analysis}

Germination rates were compared among the 5 species by conducting survival analysis using the Lifetest procedure in SAS (independent variable: specimens used, dependent variable: seed excretion rate; SAS Institute). This test estimates the survival distributions and equality of the given variables, while making no assumptions about the given distributions (Dixon \& Newman 1991).

Relationships between specimen length (Fundulus heteroclitus, Sphoeroides maculatus, Lagodon rhomboides) or weight (Malaclemys terrapin, Aythya affinis) (Table 2) and seed evacuation rates were investigated using logistic regressions in $\mathrm{R}$ statistical software. The binary response variables allowed consumed seeds to be placed in either an 'excreted' or 'non-excreted' category.

In order to determine the combined effects of seed loss during gut passage and subsequent mortality prior to germination, excretion and germination rates were multiplied for each species. This proportion analysis was compared to germination rates of each control for the respective species to assess the overall germination among controls or biotic dispersers. A survivorship analysis was applied using the Cox proportional hazards model (Newman \& Dixon 1996, Proc PHREG) to each species germination rate through time while in the sediment and at the end of the experiment. This test typically assesses the probability of death throughout a given interval of time. It is used here to compare the germination of seeds that have passed through the gut of a specimen versus control seeds, thus resulting in hazard ratios where a value of $1=$ a specimen-consumed seed and control seed are equally likely to germinate by the next point in time, $<1=$ a control seed is more likely to germinate than a consumed seed by the next point in time, and $>1$ = a specimen-consumed seed is more likely to germinate than a control seed by the next point in time.

\section{RESULTS}

Excretion and germination rates of viable Zostera marina seeds varied by species and trial year and were generally highest for Fundulus heteroclitus, Sphoeroides maculatus, and Malaclemys terrapin, lowest for Aythya affinis, and moderate for Lagodon rhomboides. Excretion rates for F. heteroclitus were higher in 2010 (99\%) than in 2009 (76\%), while they decreased for S. maculatus between 2010 and 2011. $M$. terrapin had relatively high excretion rates, yet 


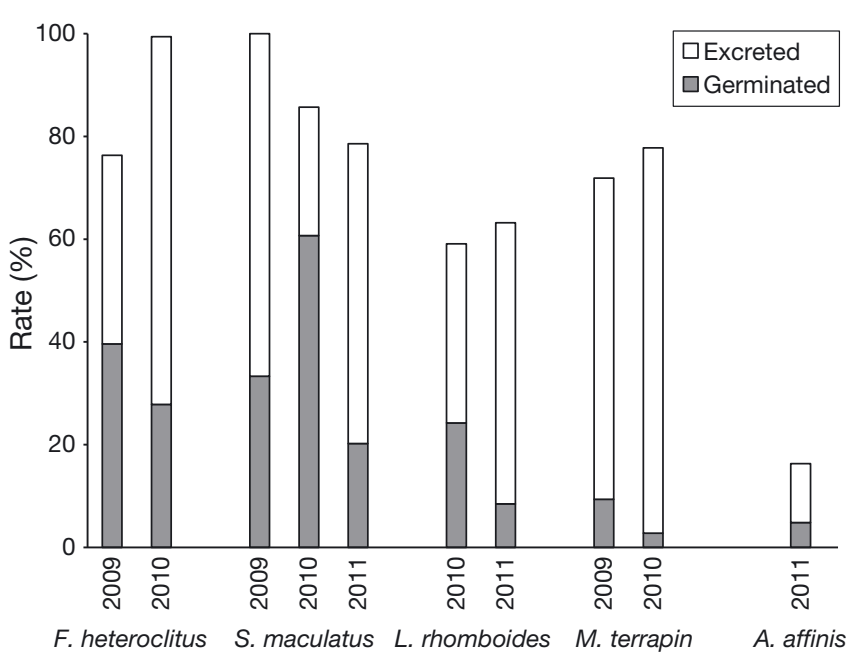

Fig. 1. Excretion and germination rates of Zostera marina seeds consumed by Fundulus heteroclitus, Sphoeroides maculatus, Lagodon rhomboides, Malaclemys terrapin, and Aythya affinis. Feeding trials were conducted in 2009, 2010, and 2011

low germination success. Overall, germination rates were highest among fish species and lowest in $A$. affinis (Fig. 1).

Observed seed retention times for passage of single seeds or beads were 15 to 20,7 to $10+, 7$ to $10+$, and 2 to $5 \mathrm{~h}$ in Fundulus heteroclitus, Sphoeroides maculatus, Lagodon rhomboides, and Aythya affinis, respectively. Retention times were estimated to be between 24 and $144 \mathrm{~h}$ for Malaclemys terrapin.

Germination success of Zostera marina seeds was assessed across all 5 species and including all trial years for each species. Post-gut passage success of seeds varied significantly by species $\left(\chi^{2}=20.926\right.$, df $=$ $4, \mathrm{p}=0.0003)$. Malaclemys terrapin had the lowest success rate among the 5 species; Fundulus heteroclitus and Sphoeroides maculatus had among the highest germination success (Table 3).

Germination rates of consumed seeds compared to control seeds indicated the feeding matrix had an effect on seed survival in Malaclemys terrapin (in 2010) and Lagodon rhomboides and Sphoeroides maculatus (both in 2011) (Fig. 2). Controls suggest gut passage has little effect on survival in $S$. maculatus (in 2010) and Fundulus heteroclitus (in 2010), yet increases the chance of seed mortality when passing through guts of Aythya affinis (Fig. 2).

In 5 instances hazard ratios had significant values, indicating the seed survivorship is likely being affected by the gut of the animal: Malaclemys terrapin (in 2010), Lagodon rhomboides (in 2010, 2011), and Sphoeroides maculatus (in 2011) when comparing the feeding trial against the seawater control, and
Table 3. Total proportion of seeds germinated for all species and individuals used throughout the trial years

\begin{tabular}{|lccc|}
\hline Taxon & Trial years & $\begin{array}{c}\text { No. of } \\
\text { individuals }\end{array}$ & $\begin{array}{c}\text { Proportion } \\
\text { germinated }\end{array}$ \\
\hline Fundulus heteroclitus & $2009-2010$ & 31 & 0.39 \\
Malaclemys terrapin & $2009-2010$ & 17 & 0.14 \\
Sphoeroides maculatus & $2009-2011$ & 12 & 0.37 \\
Lagodon rhomboides & $2010-2011$ & 24 & 0.32 \\
Aythya affinis & 2011 & 4 & 0.30 \\
\hline
\end{tabular}

Aythya affinis when comparing the feeding trial against the control with food and dye (Table 4). Hazard ratios indicated better germination via the consumed seed when feeding trials were compared to both controls in S. maculatus (in 2010). Values were closest to being equal for all feeding trials against all controls and all years in Fundulus heteroclitus (Table 4).

Specimen size had little effect on seed survival during gut passage: Fundulus heteroclitus (in 2010) ( $\left.Z=0.143_{0.101,175}, \mathrm{p}=0.886\right)$, Lagodon rhomboides $\left(Z=1.549_{0.025,61}, \mathrm{p}=0.121\right)$ and Sphoeroides maculatus $\left(Z=1.858_{0.016,56}, \mathrm{p}=0.063\right)$. Fish length did have a significant effect on seed emergence post-consumption in F. heteroclitus trials in 2009 when seeds were possibly re-ingested $\left(Z=3.889_{0.03,201}, \mathrm{p}=0.0001\right.$; Table 4). Seed passage time was not correlated with the weight of Malaclemys terrapin $\left(Z=0.249_{0.005,60}\right.$, $\mathrm{p}=0.803$ ), while weights of Aythya affinis did have a significant effect on seeds $\left(Z=5.064_{0.008,969}, \mathrm{p}=\right.$ $\left.4.11 \times 10^{-7}\right)$.

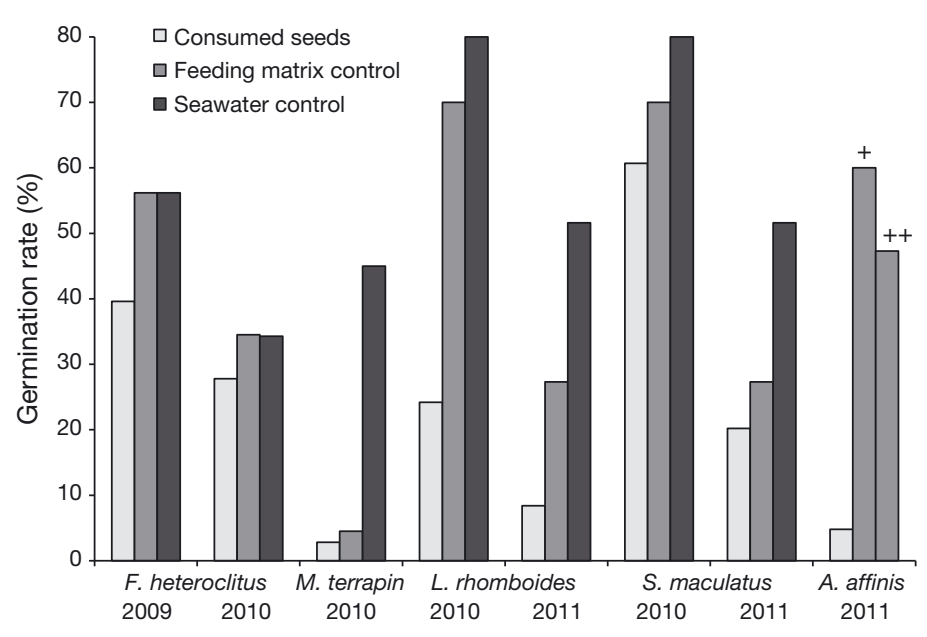

Fig. 2. Germination rate (\%) of Zostera marina seeds in controls compared to experimental treatments for seeds consumed by Fundulus heteroclitus, Malaclemys terrapin, Lagodon rhomboides, Sphoeroides maculatus, and Aythya affinis. For A. affinis: +: control seeds with feeding matrix and dye marker; ++: control seeds with feeding matrix 
Table 4. Cox proportional hazard model survivorship analysis for each species and year of feeding trial compared to controls with and without feeding matrices. Hazard models are used here to determine germination of consumed versus control seeds. PE: parameter estimate; SE: standard error; $H$ : hazard ratio; +: control seeds with feeding matrix and dye marker; ++: control seeds with feeding matrix; ${ }^{*} \mathrm{p} \leq 0.05$

\begin{tabular}{|c|c|c|c|c|c|c|c|c|c|c|c|}
\hline Taxon & Year & $\mathrm{PE}$ & $\mathrm{SE}$ & $\chi^{2}$ & $\mathrm{p}$ & $H$ & $\mathrm{PE}$ & $\mathrm{SE}$ & $\chi^{2}$ & $\mathrm{p}$ & $H$ \\
\hline Malaclemys terrapin & 2010 & -0.519 & 1.414 & 0.135 & 0.713 & 0.595 & -2.788 & 1.054 & 6.99 & $0.008^{*}$ & 0.062 \\
\hline Sphoeroides maculatus & $\begin{array}{l}2010 \\
2011\end{array}$ & $\begin{array}{r}0.378 \\
-0.137\end{array}$ & $\begin{array}{l}0.378 \\
0.387\end{array}$ & $\begin{array}{l}1.001 \\
0.125\end{array}$ & $\begin{array}{l}0.317 \\
0.723\end{array}$ & $\begin{array}{l}1.46 \\
0.872\end{array}$ & $\begin{array}{c}0.119 \\
-0.8173\end{array}$ & $\begin{array}{l}0.349 \\
0.359\end{array}$ & $\begin{array}{l}0.116 \\
5.167\end{array}$ & $\begin{array}{l}0.734 \\
0.023^{*}\end{array}$ & $\begin{array}{l}1.126 \\
0.442\end{array}$ \\
\hline Aythya affinis & 2011 & $-0.868+$ & $0.305+$ & $8.11+$ & $0.004+^{*}$ & $0.42+$ & $-0.427++$ & $0.364++$ & $1.378++$ & $0.24++$ & $0.652++$ \\
\hline
\end{tabular}

Table 5. Seed retention times estimated from single seeds or beads, recorded daily movement and maximum distances traveled for each species, are combined to estimate seed dispersal distances for each species. nd = no data

\begin{tabular}{|c|c|c|c|c|c|}
\hline Species & $\begin{array}{c}\text { Observed } \\
\text { gut retention } \\
\text { time }(\mathrm{h})\end{array}$ & $\begin{array}{l}\text { Daily } \\
\text { movement } \\
\text { (m) }\end{array}$ & $\begin{array}{l}\text { Maximum } \\
\text { distance } \\
\text { traveled }(\mathrm{m})\end{array}$ & $\begin{array}{l}\text { Dispersal } \\
\text { estimate } \\
\text { (m) }\end{array}$ & Sources \\
\hline Fundulus heteroclitus & $15-20$ & 200 & $600-3600$ & 200 & Skinner et al. (2005) \\
\hline Sphoeroides maculatus & $7-10+$ & nd & nd & nd & Present study \\
\hline Lagodon rhomboides & $7-10+$ & nd & 60 & $0-60$ & Potthoff \& Allen (2003) \\
\hline Malaclemys terrapin & $24-144$ & 1430 & 8000 & 1500 & $\begin{array}{l}\text { Ernst \& Lovich (2009), } \\
\text { D. Tulipani (pers. comm.) }\end{array}$ \\
\hline Aythya affinis & $2-5$ & $2000-37500$ & $93500 d^{-1}$ & $2000-19500$ & Herring \& Collazo (2005), Afton (2009) \\
\hline
\end{tabular}

In the 2010 feeding trials, 204 seeds did not germinate, but 30 still had intact and rigid seed coats. None of these 30 seeds stained with tetrazolium, suggesting these seeds were also non-viable. In the 2011 germination trials, 131 seeds did not germinate, but 35 had intact and rigid seed coats. Only 3 stained positively with tetrazolium, suggesting these seeds were viable.

Maximum dispersal distances were calculated as the product of literature reported values of species movements and estimates of observed seed retention times in guts (Table 5) for Fundulus heteroclitus, Lagodon rhomboides, Malaclemys terrapin, and Aythya affinis and were determined to be 200,60, 1500, and 19500 m, respectively (Fig. 3). No movement data were available for Sphoeroides maculatus, but a dispersal distance may be expected in the range of $F$. heteroclitus and $L$. rhomboides (Able \& Fahay 2010).

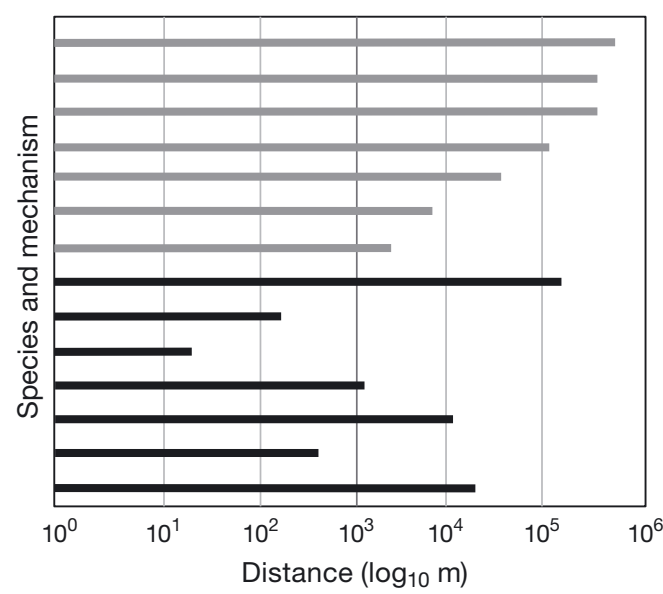

Enhalus acroides (floating fruit) Thalassia hemprichii (floating fruit) Thalassia testudinum (floating fruit) Posidonia australis (floating fruit) Thalassia hemprichii (floating seed) Enhalus acroides (floating seed) Thalassia testudinum (floating seed) Zostera marina (floating reproductive shoot) Zostera marina (floating seed) Zostera marina (seeds on sediment) Zostera marina (Fundulus heteroclitus)^ Zostera marina (Malaclemys terrapin)^ Zostera marina (Lagodon rhomboides)^ Zostera marina (Aythya affinis)^
Fig. 3. Abiotic and biotic dispersal mechanisms and distances of seagrass species (modified from Kendrick et al. 2012). Black bars represent dispersal of Zostera marina seeds; gray bars represent seed dispersal in seagrasses other than Z. marina. ${ }^{\wedge}$ : biotic dispersal 


\section{DISCUSSION}

Three years of feeding experiments indicated that Zostera marina seeds could survive passage through the guts of species in very different functional groups (fishes, turtles, birds) and successfully germinate. This is the first study to date to demonstrate survival of $Z$. marina seeds after ingestion by an animal, and provides evidence that biotic dispersal of $Z$. marina seeds is possible and needs to be considered in the dispersal dynamics of this species.

\section{Seed excretion and germination}

Excretion and germination rates varied among the 5 species both within and between years and may be a function of both foraging ecology and gut morphology of the individual species. Excretion rates of Lagodon rhomboides were lowest of the fish species used, and survivorship analyses yielded hazard ratios suggesting loss of seeds due to gut morphology in both 2010 and 2011. Other species showing significant effects from digestive tracts on seeds included Malaclemys terrapin (in 2010), Sphoeroides maculatus and Aythya affinis (both in 2011), suggesting mechanical or chemical weakening of the seed coat while in the gut of these species (Baskin \& Baskin 1998). Similar effects were apparent when comparing germination rates of experimental treatments to controls. Results of each test suggest either gut morphology or feeding behavior is damaging some of the seeds in the species used in these experiments. $L$. rhomboides are primarily herbivorous at the size range used here, with dentition to crush seeds prior to entering the digestive tract and an extended intestine for further breakdown of plant material (Stoner \& Livingston 1984, Luczkovich et al. 1995). A. affinis also feeds directly on seagrass and contains a gizzard comprised of grit to grind and break down plant cell walls (Cottam et al. 1944). M. terrapin selectively chooses epifauna, such as barnacles (D. Tulipani pers. comm.), which are broken down in the buccal cavity before entering the digestive tract. Secondarily consumed seeds are subject to this process (Bels et al. 1998). S. maculatus have beak-like jaws used to feed on and crush shelled invertebrates (Targett 1979). In addition, it is possible that our use of feeding matrices influenced overall seed mortality; it is likely that fewer seeds are destroyed when offered in combination with other food. However, despite our observations that all species used here have the capacity to damage seeds during the feeding and digestive processes and that the added feeding matrices may have influenced overall mortality, our data show that a number of seeds can successfully pass through their guts and germinate.

Lengths and weights of species generally had little effect on seed survival. Specimen length had a significant effect on seed excretion rate for Fundulus heteroclitus in the 2009 experiments, but not in 2010, when re-consumption of seeds within the 24 to $48 \mathrm{~h}$ feeding was eliminated, suggesting that fish length may not be a factor here. Weights of Aythya affinis also had a significant effect on excretion rates. It is more likely that the small sample size contributed to this value.

\section{Seed-dispersal distances}

A critical component of dispersal is the distance a seed moves from its parent to a location suitable for germination, growth, and survival (Harper 1977, Nathan \& Muller-Landau 2000). In biotic dispersal that distance is a function of how long a seed remains in the gut and how far the individual moves during that time period (Figuerola et al. 2010). Estimated dispersal distances assume linear movement, which could overestimate a dispersal calculation if a species changes directions during movements (Table 5). Our estimates compare favorably with several mechanisms of abiotic dispersal for Zostera marina and other seagrass species (Fig. 3) (Kendrick et al. 2012), with the possible exception of Aythya affinis and Malaclemys terrapin where dispersal may exceed abiotic distances. We think dispersal distances of waterfowl may exceed what we have noted here. The seed retention times we observed for $A$. affinis were relatively short compared to published literature values which exceed $24 \mathrm{~h}$ in some species (Charalambidou et al. 2003, Figuerola et al. 2010), suggesting that waterfowl that ingest $Z$. marina seeds may disperse seeds much further than the reported distances for A. affinis.

While the majority of biotic consumers will likely transport seeds shorter distances than abiotic mechanisms (Fig. 3), we suggest there may be distinct advantages for seeds dispersed by biotic mechanisms. Biotic dispersers are typically either permanent or transient residents of seagrass beds and are free to move within or between beds (Orth \& Heck 1980). In dense seagrass areas, much of the habitat range of a biotic disperser may also be suitable for seagrass growth. Species foraging either directly or indirectly on the grass will likely reside within suit- 
able growth areas to remain close to food sources, thus increasing their effectiveness as a dispersal agent. In contrast, abiotic dispersal is limited in movement by wind and currents (Kendrick et al. 2012), and, once exported from the seagrass bed, seeds could arrive in areas not suitable for seagrass growth, e.g. intertidal areas or regions of low salinity. Occasionally, biotic dispersers may aid in seagrass survival when scarification due to acidification or chemical weathering in the gut prompts early germination (Baskin \& Baskin 1998, Herrera 2002). In many cases successful biotic dispersal adds to the genetic diversity of existing seagrass beds or may establish new seagrass populations in areas distant from established beds (Howe \& Smallwood 1982, Olivieri et al. 1995, Herrera 2002).

Biotic dispersal of seagrass seeds may be more common than previously considered (Kendrick et al. 2012). Most seagrass beds support dense assemblages of small and large consumers (Thayer et al. 1984, Valentine \& Heck 1999), a number of which are seasonally transient (Adams 1976, Orth \& Heck 1980) and are potential consumers of seeds. A number of field studies have reported terrestrial and macrophyte seeds in waterfowl feces and digestive tracts that are either directly consumed or indirectly when foraging for benthic invertebrates (Guppy 1906, Baldwin \& Lovvorn 1994, Ntiamoa Baidu et al. 1998, Mueller 1999, Green et al. 2002, Figuerola et al. 2010). In addition, tropical seagrass beds support omnivorous fishes and megafauna, such as manatees, dugongs, and green turtles, capable of applying intense grazing pressure and possibly consuming large quantities of seeds in the process (Thayer et al. 1984, Preen 1995, Valentine \& Heck 1999, McDermid et al. 2007, Kendrick et al. 2012). These megafauna forage within ranges of 0 to $15 \mathrm{~km}^{2}$ and 0 to $50 \mathrm{~km}^{2}$ for manatees and dugongs, respectively, or travel 0.6 to $3.3 \mathrm{~km} \mathrm{~h}^{-1}$ for green turtles (Godley et al. 2002, Deutsch et al. 2003, Sheppard et al. 2006). Seeds surviving gut passage of these vertebrates are capable of being dispersed distances greatly exceeding those of abiotic mechanisms (Fig. 3).

\section{CONCLUSIONS}

Our first-order experiments conducted here in a laboratory setting conclusively prove that Zostera marina seeds can be ingested, excreted whole, and germinate successfully, by a variety of vertebrate species. Given that several studies have found seagrass seeds in guts of fishes and birds, we suggest that successful dispersal via biotic mechanisms may be more common than previously considered (Kendrick et al. 2012). As it is highly likely that many seeds are ingested indirectly during foraging activities of a particular species, subsequent studies should begin to focus on seed ingestion rates under field conditions when species have a diversity of food choices. The density of grass consumers also influences the likelihood and frequency of indirect seed dispersal. Seed ingestion rates may be high in tropical areas where grazing is more intense, particularly by large herbivores, such as dugongs and turtles. More importantly, the ability of seeds to successfully pass through the gut of a waterfowl species offers support for a mechanism of long-distance dispersal, as this group of vertebrates is numerically important in many areas of the world (Clausen et al. 2002, Green et al. 2002). While seeds will suffer mortality during the ingestion and digestive processes, some proportion of seeds can be expected to survive, germinate, and grow to adult plants, leading to the colonization of new habitats (Nathan et al. 2008). Finally, our data suggest that future seagrass dispersal models should incorporate biotic dispersal mechanisms.

Acknowledgements. This work was funded by a Virginia Institute of Marine Science (VIMS) student assistantship and the 2011 VIMS student research grant. The authors thank personnel from the USGS Patuxent Wildlife Research Center, the VIMS SAV laboratory, S.E.S.'s thesis committee, fellow VIMS students, especially Diane Tulipani, and faculty for their assistance in collecting specimens and analyzing data. We appreciated the excellent comments from 3 anonymous reviewers. This is Contribution No. 3253 from the VIMS.

\section{LITERATURE CITED}

Able KW, Fahay MP (2010) Sphoeroides maculatus (Bloch and Schneider) northern puffer. In: Ecology of estuarine fishes: temperate waters of the western North Atlantic. The Johns Hopkins University Press. Baltimore, MD, p 494-500

Adams SM (1976) Feeding ecology of eelgrass fish communities. Trans Am Fish Soc 105:514-519

Afton AD (2009) Chronology and rates of migratory movements, migration corridors, and habitats used throughout the annual cycle by female lesser scaup radio-marked on pool 19 of the Mississippi River. Annual Progress Report, 30 November, 2009. USGS Louisiana Cooperative Fish and Wildlife Unit, Baton Rouge, LA

Agami M, Waisel Y (1986) The role of mallard ducks (Anas platyrhynchos) in distribution and germination of seeds of the submerged hydrophyte Najas marina L. Oecologia 68:473-475

Agami M, Waisel Y (1988) The role of fish in distribution and germination of seeds of the submerged macrophytes 
Najas marina L. and Ruppia maritima L. Oecologia 76: 83-88

Baldwin J, Lovvorn J (1994) Expansion of seagrass habitat by the exotic Zostera japonica, and its use by dabbling ducks and brant in Boundary Bay, British Columbia. Mar Ecol Prog Ser 103:119-127

Baskin CC, Baskin JM (1998) Seeds. Ecology, biogeography, and evolution of dormancy and germination. Academic Press, San Diego, CA

$>$ Bels VL, Davenport J, Renous S (1998) Food ingestion in the estuarine turtle Malaclemys terrapin: comparison with the marine leatherback turtle Dermochelys coriacea. J Mar Biol Assoc UK 78:953-972

> Chambers JC, MacMahon JA (1994) A day in the life of a seed: movements and fates of seeds and their implications for natural and managed systems. Annu Rev Ecol Syst 25:263-292

- Charalambidou I, Santamaria L, Langevoord O (2003) Effect of ingestion by five avian dispersers on the retention time, retrieval, and germination of Ruppia maritima seeds. Funct Ecol 17:747-753

> Churchill AC, Nieves G, Brenowitz AH (1985) Flotation and dispersal of eelgrass seeds by gas bubbles. Estuar Coasts 8:352-354

> Clark JS, Fastie C, Hurtt G, Jackson ST and others (1998) Reid's paradox of rapid plant migration. Bioscience 48: 13-24

> Clausen P, Nolet BA, Fox AD, Klaassen M (2002) Longdistance endozoochorous dispersal of submerged macrophyte seeds by migratory waterbirds in northern Europe - a critical review of possibilities and limitations. Acta Oecol 23:191-203

> Conacher CA, Poiner IR, Butler J, Pun S, Tree DJ (1994) Germination, storage, and viability testing of seeds of Zostera capricorni Aschers from a tropical bay in Australia. Aquat Bot 49:47-58

Cottam C, Lynch JJ, Nelson AL (1944) Food habits and management of American sea brant. J Wildl Manag 8:36-56

Debussche M, Isenmann P (1994) Bird-dispersed seed rain and seedling establishment in patchy Mediterranean vegetation. Oikos 69:414-426

Deutsch CJ, Reid JP, Bonde RK, Easton DE, Kochman HI, O'Shea TJ (2003) Seasonal movements, migratory behavior, and site fidelity of West Indian manatees along the Atlantic coast of the United States. Wildl Monogr 151:1-77

Dixon PM, Newman MC (1991) Analyzing toxicity data using statistical models for time-to-death: an introduction. In: Newman MC, McIntosh AW (eds) Metal ecotoxicology: concepts and applications. Lewis Publishers, Chelsea, MI, p 207-242

Ernst CH, Lovich JE (2009) Turtles of the United States and Canada. Johns Hopkins University Press, Baltimore, MD

Figuerola J, Green AJ (2004) Effects of seed ingestion and herbivory by waterfowl on seedling establishment: a field experiment with widgeongrass Ruppia maritima in Doñana, south-west Spain. Plant Ecol 173:33-38

> Figuerola J, Green AJ, Santamaria L (2002) Comparative dispersal effectiveness of widgeongrass seeds by waterfowl wintering in south-west Spain: quantitative and qualitative aspects. J Ecol 90:989-1001

Figuerola J, Green AJ, Santamaria L (2003) Passive internal transport of aquatic organisms by waterfowl in Donana, south-west Spain. Glob Ecol Biogeogr 12:427-436

Figuerola J, Charalambidou I, Santamaria L, Green AJ
(2010) Internal dispersal of seeds by waterfowl: effect of seed size on gut passage time and germination patterns. Naturwissenschaften 97:555-565

Godley BJ, Richardson S, Broderick AC, Coyne MS, Glen F, Hays GC (2002) Long-term satellite telemetry of the movements and habitat utilization by green turtles in the Mediterranean. Ecography 25:352-362

Green EP, Short FT (2003) World atlas of seagrasses. University of California Press, Berkeley, CA

Green AJ, Figuerola J, Sánchez MI (2002) Implications of waterbird ecology for the dispersal of aquatic organisms. Acta Oecol 23:177-189

Guppy HB (1906) Observations of a naturalist in the Pacific between 1891 and 1899. Vol 2, Plant dispersal. Macmillan, London

Harper JL (1977) Population biology of plants. Academic Press, New York, NY

Harwell MC, Orth RJ (2002) Long-distance dispersal potential in a marine macrophyte. Ecology 83:3319-3330

Herrera CM (2002) Seed dispersal by vertebrates. In: Herrera CM, Pellmyr O (eds) Plant animal interactions: an evolutionary approach. Blackwell Publishing, Malden, MA, p 185-210

Herring G, Collazo JA (2005) Habitat use, movements and home range of wintering lesser scaup in Florida. Waterbirds 28:71-78

> Higgins SI, Nathan R, Cain M (2003) Are long-distance dispersal events in plants usually caused by nonstandard means of dispersal? Ecology 84:1945-1956

> Howe HF, Smallwood J (1982) Ecology of seed dispersal. Annu Rev Ecol Syst 13:201-228

$>$ Kendrick GA, Waycott M, Carruthers TJB, Cambridge ML and others (2012) The central role of dispersal in the maintenance and persistence of seagrass populations. Bioscience 62:56-65

> Levin SA, Muller-Landau HC, Nathan R, Chave J (2003) The ecology and evolution of seed dispersal: a theoretical perspective. Annu Rev Ecol Evol Syst 34:575-604

Luczkovich JJ, Norton SR, Gilmore RG (1995) The influence of oral anatomy on prey selection during the ontogeny of two percoid fishes, Lagodon rhomboides and Centropomus undecimalis. Environ Biol Fishes 44:79-95

> Marion SM, Orth RJ (2010) Innovative techniques for largescale seagrass restoration using Zostera marina (eelgrass) seeds. Restor Ecol 18:514-526

McDermid KJ, Stuercke B, Balazs GH (2007) Nutritional composition of marine plants in the diet of the green sea turtle (Chelonia mydas) in the Hawaiian Islands. Bull Mar Sci 81:55-71

Moore KA, Short FT (2006) Zostera: biology, ecology, and management. In: Larkum AWD, Orth RJ, Duarte CM (eds) Seagrasses: biology, ecology and conservation. Springer, Dordrecht, p 361-386

Moore KA, Orth RJ, Nowak JF (1993) Environmental regulation of seed germination in Zostera marina L. (eelgrass) in Chesapeake Bay: effects of light, oxygen and sediment burial. Aquat Bot 45:79-91

Mueller H (1999) Common snipe Gallinago gallinago. In: Grill F (ed) The birds of North America, No. 417. The Birds of North America Inc., Philadelphia, PA

> Myers JA, Vellend M, Gardescu S, Marks PL (2004) Seed dispersal by white-tailed deer: implications for longdistance dispersal, invasion, and migration of plants in eastern North America. Oecologia 139:35-44

Nathan R, Muller-Landau HC (2000) Spatial patterns of seed 
dispersal, their determinants and consequences for recruitment. Trends Ecol Evol 15:278-285

Nathan R, Schurr FM, Spiegel O, Steinitz O, Trakhtenbrot A, Tsoar A (2008) Mechanisms of long-distance seed dispersal. Trends Ecol Evol 23:638-647

Newman MC, Dixon PM (1996) Ecologically meaningful estimates of lethal effect in individuals. In: Newman MC, Jagoe CH (eds) Ecotoxicology a hierarchical treatment. CRC Press, Boca Raton, FL, p 225-254

Ntiamoa-Baidu Y, Piersma T, Wiersma P, Poot M, Battley P, Gordon C (1998) Water depth selection, daily feeding routines and diets of waterbirds in coastal lagoons in Ghana. Ibis 140:89-103

Olivieri I, Michalakis Y, Gouyon PH (1995) Metapopulation genetics and the evolution of dispersal. Am Nat 146: 202-228

Orth RJ, Heck KL Jr (1980) Structural components of eelgrass (Zostera marina) meadows in the lower Chesapeake Bay-fishes. Estuaries 3:278-288

Orth RJ, Luckenbach M, Moore KA (1994) Seed dispersal in a marine macrophyte: implications for colonization and restoration. Ecology 75:1927-1939

Orth RJ, Harwell MC, Inglis J (2006) Ecology of seagrass seeds and seagrass dispersal processes. In: Larkum AWD, Orth R, Duarte CM (eds) Seagrasses: biology, ecology and conservation. Springer, Dordrecht, p 111-133

Potthoff MT, Allen DM (2003) Site fidelity, home range, and tidal migrations of juvenile pinfish, Lagodon rhomboides, in salt marsh creeks. Environ Biol Fishes 67:

Editorial responsibility: Kenneth Heck Jr., Dauphin Island, Alabama, USA
$231-240$

> Preen A (1995) Impacts of dugong foraging on seagrass habitats: observational and experimental evidence for cultivation grazing. Mar Ecol Prog Ser 124:201-213

- Sheppard JK, Preen AR, Marsh H, Lawler IR, Whiting SD, Jones RE (2006) Movement heterogeneity of dugongs, Dugong dugon (Müller) over large spatial scales. J Exp Mar Biol Ecol 334:64-83

Skinner MA, Courtenay SC, Parker WR, Curry RA (2005) Site fidelity of mummichogs (Fundulus heteroclitus) in an Atlantic Canadian estuary. Water Qual Res J Canada 40: 288-298

> Stoner AW, Livingston RJ (1984) Ontogenetic patterns in diet and feeding morphology in sympatric sparid fishes from seagrass meadows. Copeia 1984:174-187

Targett TE (1979) A contribution to the biology of the puffers Sphoeroides testudineus and Sphoeroides spengleri from Biscayne Bay, Florida. Fish Bull 77:292-295

Thayer GW, Bjorndal KA, Ogden JC, Williams SL, Zieman JC (1984) Role of larger herbivores in seagrass communities. Estuaries 7:351-376

> Valentine JF, Heck KL Jr (1999) Seagrass herbivory: evidence for the continued grazing of marine grasses. Mar Ecol Prog Ser 176:291-302

> Wilkinson DM (1997) Plant colonization: Are wind dispersed seeds really dispersed by birds at larger spatial and temporal scales? J Biogeogr 24:61-65

> Wilkinson DM (1999) Birds and seed dispersal; a response to comments by F. M. Chambers. J Biogeogr 26:429-430

Submitted: June 11, 2012; Accepted: October 26, 2012

Proofs received from author(s): November 30, 2012 